\title{
Correction to: Displacement and frequency response measurements of a ship using GPS and fibre optic-based sensors
}

\author{
Gethin Wyn Roberts ${ }^{1,2}$ (D) $\cdot$ CraigMatthew Hancock $^{3} \cdot$ Werner Lienhart ${ }^{4} \cdot$ Ferdinand Klug $^{4} \cdot$ Niko Zuzek $^{4} \cdot$ Huib de Ligt $^{4}$ \\ Published online: 16 October 2020 \\ (C) Società Italiana di Fotogrammetria e Topografia (SIFET) 2020
}

\section{Correction to: Applied Geomatics https://doi.org/10.1007/s12518-020-00338-z}

The original version of this article unfortunately contained a mistake. The caption of Fig. 5 was incorrect. The corrected caption is given below.

Fig. 5 Location of the GPS antennas and FBG sensors on the Smyril (background Image courtesy of Strandfaraskip Landsins)

The original article has been corrected.

The online version of the original article can be found at https://doi.org/ $10.1007 / \mathrm{s} 12518-020-00338-\mathrm{Z}$

Gethin Wyn Roberts

gethinr@us.fo

CraigMatthew Hancock

craig.hancock@nottingham.edu.cn

Werner Lienhart

werner.lienhart@ tugraz.at

Ferdinand Klug

Ferdinand.klug@tugraz.at

Niko Zuzek

zuzek@student.tugraz.at
Huib de Ligt

huib.deligt@nottingham.edu.cn

Environment Agency of the Faroe Islands (Umhvørvisstovan), Tórshavn, Faroe Islands

2 The University of the Faroe Islands, Tórshavn, Faroe Islands

3 The University of Nottingham Ningbo China, Ningbo, China

4 Graz University of Technology, Graz, Austria 